\title{
Electoral Politics and Women Participation in Nigeria: A Case St udy of 2003, 2007 \& 2011 General Elections In Ekiti State.
}

\author{
Oluwatusin, Adebowale O.\& Arowosegbe Christiana K.
}

\begin{abstract}
Nigerian women are known to play vital roles as mothers, producers, time managers, community or ganizers and socio-political activists. But despite the major roles they play and their population, the society has not given recognition to this and to the fact that they are discriminated against. The Nigerian society being a pat riarchal one, clearly manifests the social categorization of women implicit as being inferior to men and therefor $e$, not capable or suitable for political leadership. This study therefore, is an assessment of women participation in electoral politics using 2003, 2007 and 2011 general elections in Ekiti State, Nigeria as its focus.

Available data on the elections were collected from the electoral body responsible for the conduct of el ections in the country- Independent National Electoral Commission (INEC)- to determine the level of involveme nt of women in the elections. It was discovered in the study that, despite the political enlightenment campaigns, women's participation in electoral politics is still at the lowest ebb. The study therefore highlights the factors th at are inhibiting women active participation in electoral politics and makes suggestions on the way forward.
\end{abstract}

\section{Introduction}

Politics is viewed as a phenomenon that evokes a great deal of apprehension and uneasiness among ord inary citizens all over the world (Olufemi 2003).The situation in Nigeria has gone to a level that the popular per ception of politics is that of a "dirty game". This stems from the unwholesome behaviours of politicians, their po liticalmanoeuvres and manipulations, electoral practices, violence and killings. The tendency is for decent peopl e to want to steer clear of politics and politicians as much as possible. Yet,every human being is a political anim al; politics affects our lives in every available facet. Participation of citizens in competitive politics is a distingui shing feature of democracy.Sequel to the above, the participation of women in partisan politics has also been use $\mathrm{d}$ as a key indicator for measuring the general level of democratization in any given society. This is so because, being a historically oppressed and marginalized group - but ironically constituting half of the national populatio $\mathrm{n}$ - their level of involvement in political activities is crucial to the understanding of the level of political develo pment in any country.

This paper addresses itself to women participation in electoral politics in Nigeria with particular referen ce to 2003, 2007\& 2011 general elections in Ekiti State. The paper highlights the factors militating against activ e women participation in electoral politics and makes suggestions on the way forward.

\subsection{ConceptualisingElection and Political Participation}

Election originated with democracy in order to make leadership succession easy by allowing the citizen ry to participate in the selection of their leaders. Also, Omotoso(2002) conceives election as one among several $t$ ools used by power contenders to gain office, which also provides the opportunity for smooth transfer of politica 1 power from individuals to individuals and from groups to groups. Thus, elections ensure the participation of citi zens in the democratic process both as candidates and electorate. It is through the system of elections that the pe ople express their wishes especially in the choice of those who govern them. Moreover, election as the major so urce of political mandate, serves both as a reminder of campaign promises by candidates and both legal and mor al ground for the candidates to remain accountable to the electorate (Olaoye, 2007). However, Anifowose (2003 ) summarises the functions of elections to include recruiting politicians and public decision-makers; making gov ernments; influencing policy decision; educating voters; building legitimacy; strengthening elites; providing suc cession in leadership; and extension of participation to many people. It has also been observed that countries wit $\mathrm{h}$ developed economies are expected to have higher level of electoral participation because of its consequences o $\mathrm{n}$ participation. The more economically strong citizens are, the higher the potential for mobilizing them for politi cal participation.

Participation of citizens in electoral politics on the other hand, is not only a civic responsibility, buta ba sic ingredient of democracy. In particular, full participation within the local institutions contributes to the creatio $\mathrm{n}$ of community solidarity because everyone feels involved in what is going on relative to his/her welfare. Thus, individual full participation boils down to popular participation and is expected to express their wishes on issues
o
$\mathrm{f}$
g
o
v e
$n$
a
$n$
c e 
Thus, it can be argued that political participation is not only relevant to the individual but also crucial $\mathrm{t}$ o the state or nation as its survival is contingent on the extent to which the citizens are involved in its activities. One can say here that the extent of individual participation in the political process also gives a basic idea of the 1 evel of development of that society; although the level of development of a particular society can sometimes infl uence the extent of political participation of the citizenry. Nevertheless, political participation which entails the voluntary involvements of the citizens in the choice of leaders and in the policy formulation and implementation process of their society affords the people a sense of belonging and a say in how they are being governed. Politi cal participation, according to Igwe (2002):335) is the degree and forms of involvement of the people in governa nce and related institutions of society, such as the economy and culture. In its active sense, it involves participati on in political campaigns and debates, attending caucus or strategic meetings of political parties, voting during e lections, contesting, attending meetings and rallies as candidates for elections and holding of party positions. Ok olie's (2004:53) definition goes beyond this to include freedom of expression, association, right to free flow of c ommunication, influence decision making process and right to social justice. According to him, it also expresses such rights to demand for better social and health service, better working conditions and increase in wages, amo ngst others.

Epelle\&Oriakhi (2003: 60-61) reduce political participation to the following activities:

$((((1) \quad$ Voting at elections,

$((((2) \quad$ Belonging to a political party,

( ((3) Contesting for positions within the party;

$(((4) \quad$ Vying for positions in the state whether at the local, regional or national levels,

$((((5) \quad$ Attending party meetings and campaigns,

$((((6) \quad$ Holding and expressing political opinions and

( ((7) Belonging to community-based organisations or other non-governmental organisations(NGOs) that have leadership interest.

A critical look at the above activities shows that Nigerian women have been involved mainly at the first one and lately the last one, that is, voting at general elections after which they retire to their kitchens only to re-a ppear on the voting queue during the next election; and belonging to community-based organisations and NGOs which is tied to their getting empowered economically rather than politically. Women are increasingly associatin $\mathrm{g}$ with these groups in a bid to take advantage of the services rendered by the associations. Supporting this, Soet an (1995: 87) in her findings, submits:

\section{Majority of the members of women's association and non-members agreed that access to resources would be difficult without membership of women's associations. It is thus quite clear that women's associations do indeed empower their members economically. They are recognized as the appropriate organs of empowerment for women within their communities.}

However, before a political action can occur, the political actor must have picked up relevant stimuli fr om the environment. The general preposition relating stimuli and political participation is such that the more sti muli about politics a person receives, the greater the likelihood that he/she will participate in politics, and the gr eater the depth of his/her participation (Milbrath, 1965). Stimuli exist in the environment of a political actor, and the exposure to him/her increases the quantity and sharpness of political knowledge, stimulates interest, and con tributes to the decisiveness of political choices. (Quadri, 2004).

In relating political attitudes to the structure of politics, the political culture of a nation becomes signifi cant. Political culture may refer to specific political orientations- attitudes towards the political systems and its $\mathrm{v}$ arious parts, and attitudes towards the role of self in the system (Almond \&Verba, 1963). Hence, the political cu lture of a nation is the particular distribution of patterns of orientation towards political objects among the memb ers of the nation. Amongst the factors determining this attitude is the early socialisation experience which signifi cantly affects an individual's basic personality and predispositions and may, therefore affect his/her political be haviours. The non-political authority pattern to which an individual is exposed also affects his/her political behav ior. The authority patterns in the family are the first exposure to authority. In many societies, (Nigeria inclusive), women are raised from childhood not to exhibit any form of ideological tendencies that could prepare them for 1 eadership roles. They are trained from birth to grow up to be good wives and mothers. Ogunlesi (2000) gives an insight into this:

The traditional role of women is at the domestic level, to look after their husband and assist on the farm - in rural communities and augment the family income by carrying out some trading. Young girls assisted their mothers in cleaning the house, 
Thus, due to no fault of theirs, women see most things as the exclusive preserve of men. Nda (2003:336 ), contributing further on the structure of hierarchy within the family, noted that it cultivates attitudinal traits of male dominance and female subservience which are often transposed into formal sectors.

\subsection{Descriptive Analysis of Ekiti State}

Ekiti State of Nigeria was created on $1^{\text {st }}$ Oct., 1996 by the late Head of State and Commander-in-Chief of Armed Forces of the Federal Republic of Nigeria, General SaniAbacha GCON in a nationwide broadcast to mar $\mathrm{k}$ the $36^{\text {th }}$ Independence anniversary of Nigeria. The state carved out of Ondo State, covers the former twelve loc al government areas that made up the Ekiti Zone of old Ondo State. However, Ekiti State, on creation took off w ith sixteen local government areas, having had additional four carved out of the old ones. They are culturally ho mogeneous and speak a dialect of Yoruba language known as Ekiti. The local dialect is spoken with slight variat ions in different communities, but this does not prevent Ekiti indigenes from understanding one another. The Ek iti whose ancestors migrated from Ile-Ife as a people, form one ofthe largest ethnic groups in Yoruba land. All t owns in Ekiti take a common suffix, "Ekiti" after their names. The state can boast of more than 127 large and s mall, ancient and modern towns located on hills and valleys that characterize the state from which the confinem ent takes its name, Ekiti that is "Okiti" meaning hill. Ekiti people are predominantly farmers but some women e ngage in cottage activities like mat-making, weaving, hair-plaiting etc. The people of Ekiti are hardworking, upr ight, studious \& very articulate. They are mostly Christians \& Muslims (Fasuan, 2002).

At its inception, Ekiti State had Capt. InuwaBawa at the helm of affairs. This is followed by Atanda Yusuf as its military administrators before the return to civil rule in 1999. Elections were conducted into the State Hou se of Assembly, local government areas, House of Representatives, The Senate and for the officeof theGovernor . Chief Niyi Adebayo emerged the winner of the gubernatorial election in 1999 and was sworn in on $29^{\text {th }}$ May, 1 999 as the first Executive Governor of the state. Other general elections were conducted in the state in 2003 whi ch brought in Mr. Ayo Fayose as the Governor. However, he could not complete his term in office due to his im peachment by the State House of Assembly in 2006. Consequently, former President OlusegunObasanjo declare $\mathrm{d}$ a state of emergency on the state in a national broadcast and imposed an Administrator (Gen. TunjiOlurin (rtd) ) on the state on $19^{\text {th }}$ October, 2006. On April 27, 2007 Olurin was replaced by Tope Ademiluyi as acting Gover nor. In 2007 elections were conducted at various levels, Governor Segun Oni was declared the winner of the gub ernatorial election and was sworn-in as the governor on $29^{\text {th }}$ May, 2007. But his government was ousted on $15^{\text {th }}$ Oct. 2010 by the judgement of the Election Tribunal sitting in Ilorin which declared Dr. KayodeFayemi as the w inner of the rerun election of 2009. During these periods, the percentage of women who got involved in the cont ests was far below that of men as would be discussed subsequently.

\subsection{Anaysis of Female Contestants in Ekiti State}

Our focus of study in this paper is on the 2003, 2007 and 2011 general elections in Ekiti State.During t hese elections, the percentage of women who got involved in the contests was far below that of men as shown in the tables below:

Table 1: 2003 Senatorial Elections: Distribution of Contestants on Gender Basis

\begin{tabular}{|c|l|l|l|l|l|}
\hline No of seats & $\begin{array}{l}\text { Total no of male con } \\
\text { testants }\end{array}$ & $\begin{array}{l}\text { Total no of female c } \\
\text { ontestants }\end{array}$ & $\begin{array}{l}\% \text { of female } \\
\text { contestants }\end{array}$ & $\begin{array}{l}\% \text { of Male } \\
\text { contestants }\end{array}$ & No female elected \\
\hline 3 & 16 & 3 & 15.8 & 84.2 & Nil \\
\hline
\end{tabular}

Source: INEC, Ado-Ekiti

Table 2: 2003 House of Assembly Elections: Distribution of Contestants on Gender Basis

\begin{tabular}{|l|l|l|l|l|l|l|}
\hline $\begin{array}{l}\text { No of seats ava } \\
\text { ilable }\end{array}$ & $\begin{array}{l}\text { Total no of con } \\
\text { testants }\end{array}$ & $\begin{array}{l}\text { Total no of mal } \\
\text { e contestants }\end{array}$ & $\begin{array}{l}\text { Total no of fe } \\
\text { male contesta } \\
\text { nts }\end{array}$ & $\begin{array}{l}\% \text { of female c } \\
\text { ontestants }\end{array}$ & $\begin{array}{l}\text { of Male } \\
\text { contestant } \\
\text { s }\end{array}$ & $\begin{array}{l}\text { No of female e } \\
\text { lected }\end{array}$ \\
\hline 26 & 145 & 140 & 5 & 3.4 & 96.6 & 1 \\
\hline
\end{tabular}

Source: INEC, Ado-Ekiti

Table 3: 2003 Governorship Elections: Distribution of Contestants on Gender Basis

\begin{tabular}{|c|l|l|l|l|l|}
\hline No of seats & No of contestants & $\begin{array}{l}\text { No of male con } \\
\text { testants }\end{array}$ & $\begin{array}{l}\text { No of female c } \\
\text { ontestants }\end{array}$ & $\begin{array}{l}\% \text { of female co } \\
\text { ntestants }\end{array}$ & $\begin{array}{l}\% \text { of Male contestant } \\
\text { s }\end{array}$ \\
\hline 1 & 8 & 8 & - & - & 100 \\
\hline
\end{tabular}

Source: INEC, Ado-Ekiti

In the 2003 Senatorial Elections in the state, Table 1 shows that there were only three women which are $15.8 \%$ of the total number of contestants (19) while $84.2 \%$ was the percentage of male contestants. None of the female contestants made it to the Senate. Table 2 also presents 2003 House of Assembly Elections with only 
five female contestants $(3.4 \%)$ out of the 145 contestants that contested for the twenty-six seats in the $\mathrm{H}$ ouse while the remaining 140 contestants were men (96.6\%) and only one woman got elected.In the same year, $t$ here was no female contestant in the Governorship Elections as seen in Table 3.

However, in 2007 there was an increase in the number of women that participated in the electoral cont est in the state but only three women got elected out of the eighteen female contestants that participated in the ge neral elections. The analyses of the eighteen contestants are shown in Tables 4-7.

Table 4: 2007 Governorship Elections: Distribution of Contestants on Gender Basis

\begin{tabular}{|l|l|l|l|l|l|l|}
\hline Post contested for & $\begin{array}{l}\text { No of all Contest } \\
\text { ants }\end{array}$ & $\begin{array}{l}\text { No of Male Conte } \\
\text { stants }\end{array}$ & $\begin{array}{l}\text { No of Female Co } \\
\text { ntestants }\end{array}$ & $\begin{array}{l}\% \text { of Female Co } \\
\text { ntestants }\end{array}$ & $\begin{array}{l}\% \text { of Male Conte } \\
\text { stants }\end{array}$ & $\begin{array}{l}\text { No of Fem } \\
\text { ale elected }\end{array}$ \\
\hline Governorship & 13 & 13 & - & - & 100 & - \\
\hline $\begin{array}{l}\text { Deputy Governors } \\
\text { hip }\end{array}$ & 13 & 10 & 3 & 23 & 77 & - \\
\hline
\end{tabular}

Source: INEC, Ado-Ekiti

Table 4 indicates that there was no female candidate for the Governorship Elections and only three wo men contested for Deputy Governorship which is $23 \%$ of the total contestants (13). None of the three women go t elected as Deputy Governor. However, there was a re-run election through the judgement of the Election Tribu nal in 2009 in which Engr. Segun Oni and his Deputy, Chief Tai Lawal were declared as winners. But this was c ontested by the Action Congress of Nigeria candidate and the Court of Appeal in Ilorin later declared the ACN g ubernatorial candidate as winner and thereafter a Female Deputy Governor emerged on $16^{\text {th }}$ October, 2010 in Ek iti State in person of Mrs. FunmilayoAdunniOlayinka. Unfortunately, the Ekiti State lost her to the cold hands of death on $6^{\text {th }}$ April, 2013 after a protracted battle with cancer. Thereafter, Prof (Mrs) ModupeAdelabu, the Chair man of Ekiti State Universal Basic Education Board was appointed as the Deputy Governor and sworn in on We dnesday, $8^{\text {th }}$ May, 2013 (Afisunlu, 2013).

Table 5: 2007 Elections into State House of Assembly: Distribution of Contestants on Gender Basis

\begin{tabular}{|c|c|c|c|c|c|c|}
\hline No of seats & $\begin{array}{c}\text { No of Contesta } \\
\text { nts }\end{array}$ & $\begin{array}{c}\text { No of Female } \\
\text { Contestants }\end{array}$ & $\begin{array}{c}\text { No of Male } \\
\text { Contestants }\end{array}$ & $\begin{array}{c}\% \text { of Female } \\
\text { Contestants }\end{array}$ & $\begin{array}{c}\% \text { of Male Con } \\
\text { testants }\end{array}$ & $\begin{array}{c}\text { No of femal } \\
\text { e elected }\end{array}$ \\
\hline 26 & 128 & 8 & 120 & 6.25 & 93.75 & - \\
\hline
\end{tabular}

Source: INEC, Ado-Ekiti

Table 6: 2007 Senatorial Elections: Distribution of Contestants on Gender Basis

\begin{tabular}{|c|c|c|c|c|c|}
\hline $\begin{array}{c}\text { No of all Contestant } \\
\text { s }\end{array}$ & $\begin{array}{c}\text { No of Male Contest } \\
\text { ants }\end{array}$ & $\begin{array}{c}\text { No of Female Conte } \\
\text { stants }\end{array}$ & $\begin{array}{c}\% \text { Female Contestan } \\
\text { ts }\end{array}$ & $\begin{array}{c}\% \text { of Male Contesta } \\
\text { nts }\end{array}$ & $\begin{array}{c}\text { No of Female elect } \\
\text { ed }\end{array}$ \\
\hline 25 & 24 & 1 & 4 & 96 \\
\hline
\end{tabular}

Table 7: 2007 House of Representatives Election: Distribution of Contestants on Gender Basis

\begin{tabular}{|c|c|c|c|c|c|c|}
\hline $\begin{array}{c}\text { No of s } \\
\text { eats }\end{array}$ & No of contestants & No of Male Contestants & $\begin{array}{c}\text { No of Female Co } \\
\text { ntestants }\end{array}$ & $\begin{array}{c}\% \text { of Female Con } \\
\text { testants }\end{array}$ & $\begin{array}{c}\% \text { of Male } \\
\text { Contestants }\end{array}$ & \begin{tabular}{c} 
No of Female elected \\
\hline 6
\end{tabular} \\
\hline 6 & 33 & 6 & 15.4 & 84.6 \\
\hline \multicolumn{5}{|c|}{ Source: INEC, Ado-Ekiti }
\end{tabular}

In Table 5, it is shown that therewere 8 female contestants $(6.25 \%)$ out of the total contestants (128) wh o contested for the 26 seats into the State House of Assembly and none of the female contestants got elected. Th ough the percentage of female contestants into House of Assembly rose from 3.4\% in 2003to 6.25\% in 2007, the re was no female elected into the House of Assembly. For the 2007 Senatorial elections, there was only one fem ale contestant $(4 \%)$ out of the total contestants (25) for the three seats in the Senate and the lone female contesta nt never got elected as indicated in Table 6. From Table 7, it is seen that the only three successful female candid ates in the 2007 general elections in Ekiti State were those elected into the House of Representatives. Out of the six seats that were contested for, women were able to get three seats even though the percentage of female conte stants $(15.4 \%)$ was very low to that of men which was $84.6 \%$.

Furthermore, in the last general elections in 2011 , for the Senatorial elections in the state, there were fo ur female contestants $(16.7 \%$ ) while the percentage of male contestants was $83.3 \%$. None of the female contesta nts got elected as shown in Table 8 below:

Table 8: 2011 Senatorial Elections: Distribution of Contestants on Gender Basis

\begin{tabular}{|l|l|l|l|l|l|l|}
\hline No of Seats & No of Contestants & $\begin{array}{l}\text { No of Female Cont } \\
\text { estants }\end{array}$ & $\begin{array}{l}\text { No of Male Contes } \\
\text { tants }\end{array}$ & $\begin{array}{l}\text { \% of Female Conte } \\
\text { stants }\end{array}$ & $\begin{array}{l}\text { \% of Male Contest } \\
\text { ants }\end{array}$ & $\begin{array}{l}\text { No of Femal } \\
\text { e Elected }\end{array}$ \\
\hline 3 & 24 & 4 & 20 & 16.7 & 83.3 \\
\hline
\end{tabular}

Source: INEC, Ado-Ekiti 
Electoral Politics And Women Participation In Nigeria: A Case Study Of 2003, 2007 \& 2011

Table 9: 2011 House of Representatives Elections: Distribution on Gender Basis

\begin{tabular}{|l|l|l|l|l|l|l|}
\hline No of Seats & No of Contestants & $\begin{array}{l}\text { No of Female Con } \\
\text { testants }\end{array}$ & $\begin{array}{l}\text { No of Male Conte } \\
\text { stants }\end{array}$ & $\begin{array}{l}\% \text { of Female Con } \\
\text { testants }\end{array}$ & $\begin{array}{l}\text { \% of Male Contest } \\
\text { ants }\end{array}$ & $\begin{array}{l}\text { No of Fema } \\
\text { le Elected }\end{array}$ \\
\hline 6 & 41 & 37 & 9.75 & 90.25 \\
\hline
\end{tabular}

Source: INEC, Ado- Ekiti

Also, Table 9 indicates the elections into the House of Representatives where there were four female co ntestants $(9.75 \%)$ and 37 male contestants $(90.25 \%)$ that contested for the six seats. The former three female rep resentatives that were elected in 2007 who re-contested did not get elected. All the seats were taken over by thei r male counterparts.

Table 10: 2011 House of Assembly Elections: Distribution on Gender Basis

\begin{tabular}{|l|l|l|l|l|l|l|}
\hline No of Seats & No of Contestants & $\begin{array}{l}\text { No of Female Con } \\
\text { testants }\end{array}$ & $\begin{array}{l}\text { No of Male Contes } \\
\text { tants }\end{array}$ & $\begin{array}{l}\% \text { 0f Female Cont } \\
\text { estants }\end{array}$ & $\begin{array}{l}\% \text { of Male Contest } \\
\text { ants }\end{array}$ & $\begin{array}{l}\text { No of Fem } \\
\text { ale Elected }\end{array}$ \\
\hline 26 & 189 & 45 & 144 & 23.8 & 76.2 & 4 \\
\hline
\end{tabular}

Source: INEC, Ado-Ekiti

From Table 10, in the 2011 House of Assembly elections, we have appreciable number of women (45) who came out to slug it out with their male counterparts (144) and four women got elected into the State House of Assembly. Even though, the percentage of the female representatives which is $15 \%$ of the no of seats (26) is 1 ow, but this was the first time that the House of Assembly has four female members whichshowed that women a re coming out of their shell to participate in electoral politics. This is still likely to increase in future but the fact still remains that the degree of improvement remains marginal and it is still far below the 1995 Beijing Declarati on which provides that $35 \%$ of all positions in government be given to women.

\subsection{Factors Militating Against Active Women Participation in the Electoral Politics}

A number of obstacles are on the path of women who intend to play active part in the electoral process of Nigeria. Some of these obstacles are simply as a result of their natural status as women - the belief that nature has consigned them to a specific role in the society. The other obstacles are man-made- a strategic ploy by their male counterparts to ease them out of the way. Some of these obstacles are discussed herein.

The inability of women to occupy party executive positions, (although, the position of women leader is reserved for them) has been seen as a major barrier to women participation in politics. There is large scale discrimination from the men folk, both in voting for candidates and in allocating political offices. More often than not, men con stitute a larger percentage of the party membership and this tends to affect women when it comes to selecting or electing candidates for party executive positions and elections. Since men are usually in majority in the political party set up, they tend to dominate the party hierarchy and are therefore at advantage in influencing the party's $i$ nternal politics. Women usually constitute a smaller percentage of political party membership because of the soc ial, cultural and religious attitudes of different Nigerian societies which most often tend to relegate women to th e background. As a result, only very few men, even among the educated, allow their wives to come out and parti cipate in the electoral process especially as "card carrying" members of political parties.

There is also the upbringing and orientation of women in Nigeria. Due to no fault of theirs, women see most things as the exclusive preserve of men. A good example is the realm of politics - women think that only men should engage in politics, that is why despite their numerical strength, they hardly influence the politics of $t$ he country. It is not surprising that we always hear of women contesting positions of deputy/vice in local or co mmunity based organization and in mainstream politics, also for vice - president, deputy governor, or party trea surer leaving the men to aspire to the number one position. This poor mindset was imposed and is still being imp osed by societal values and cultural mores where women are brought up to see themselves as inferior to their ma le counterparts.

Also, the feminine gender in its nature does not have the courage to face thehazardouspolitical situation as demonstrated by violence, thuggeryand intimidation. Naturally, women are more soft - minded than men and may not introduce violence and thuggery in their politicking. Conversely, men deploy all arsenals within their $r$ each to ensure success at the polls. Some women who would have given society good leadership but who are not strong enough to absorb the devastating effects of thuggery and political violence against them are scared away from competitive politics. Thus, it becomes generally difficult for women to swim the murky waters of Nigerian politics. They (especially those of them that are married) cannot attend midnight caucus meetings of the politica 1 parties where most often, crucial decisions are taken and offices that are supposed to be thrown open for contes $\mathrm{t}$ are shared. We are all aware that such unholy hours are not suitable for women who have children to take care of, and whose husbands are not politically inclined or the immediate family is not supportive. Our male politicia ns exploit this singular situation to scheme out the women from active participation and relegate them to "clappi
n $\mathrm{g}$
a $\mathrm{n}$ d
$\mathrm{s}$ i $\mathrm{n}$ g $\mathrm{i}$ n $\mathrm{g}$ ”
$\mathrm{p} \quad \mathrm{o}$
i
c
a $n$ s. 
Moreover, lack of adequate finance is a crucial hindrance to effective women participation in politics in Nigeria. A large number of the Nigerian women population is not as financially strong as their male counterp arts because most women do not have access to credit schemes and facilities like men. To be a successful politic ian in Nigeria,one must have money to spend because Nigerian politics is a capital-intensive venture, as meeting s, publicity, campaign strategies, have to be financed. Again women politicians are often rejected and condemne $\mathrm{d}$ by their fellow women. This may be because women politicians or women who hold top government appoint ment over the years have not been able to distinguish themselves from the crass for materialism, corruption, lac $\mathrm{k}$ of accountability that characterize Nigeria politics. Also the view that Nigerian politics is a "dirty game" influ ences the grassroots women to see those who venture into politics as dirty, wayward and even cultural deviants because of the patriarchal nature of our society and women are expected to subordinate themselves to the control of men.

More so,family responsibilities and child bearing / childrearing hinder women from participating in ele ctoral politics. The roles of women as wives, mothers and housekeepers are to be performed on a full-time basis, while any other career is regarded as secondary. Thus, much of the time they might have wished to devote to po litics is taken up by their maternal challenges and obligations.

\section{Recommendations}

To overcome these and several other obstacles militating against women's participation in politics, wo men must be proactive; they must register and obtain their voters' cards. They should also register with the politi cal party of their choice in their various wards; attend ward meetings regularly and participate in all activities in cluding campaign rallies, lectures, etc. Women should not allow men to discourage or discredit them; however, $\mathrm{t}$ hosethat are married should carry their spouses along in deciding to go into active politics. By so doing, they wil 1 be physically strengthened and morally empowered.

Women in active politics should be charismatic, hardworking and carry their personality with a conside rable degree of dignity to gain the support of their fellow women. This is also important because men respect wo men of high moral standard. No man respects any female politician who is willing to engage in immoral acts wit $\mathrm{h}$ a so-called male political godfather or benefactor.

Also, women should encourage and support fellow women who are contesting elective positions. Fundr aising dinners can be organized to raise money for female candidates and obstacles to credit schemes and faciliti es should be reviewed as they affect women. Moreover, concessions should be given to women to encourage the $\mathrm{m}$ to take up elective offices so that they can be part of the governance process. The UN Convention on the Elim ination of all forms of Discrimination Against Women (CEDAW) and other international treaties to which Niger ia is a signatory have taken this position.

More so, the social status of women should be improved (human right, equality of rights) in the realm o f law and institutions. Thus, women in parliament and government should promote women into the mainstream of big businesses so that they can influence the economy of our country and thereby improve their status which will invariably enhance their participation in the political process of the country. The wave of violence, thuggery, insecurity that characterized our politics should be arrested so that decent women and men can participate in it.

Finally, there must be a change in the socio-cultural obstacles and prejudice that readily put girls and w omen in a position of subservience and limitation thereby making it difficult for them to realize their fullest pote ntials and abilities.

\section{Conclusion}

From the foregoing, we have been able to discuss women participation in the electoral process in Niger ia using Ekiti State as our case study. We found out that the number of women that participate in politics is still very low compared to that of men as shown in the 2003, 2007 and 2011 general elections in Ekiti State. In spite of the 1995 Beijing Declaration, to which Nigeria is a signatory and which provides that $35 \%$ of all positions in government and government owned concerns be given to women, Nigerian women are yet to reap the benefits o $\mathrm{f}$ the declaration. The paper also enumerated some of the factors militating against women participation in politi cs and made recommendations as to overcoming the obstacles.

In conclusion therefore, there is still a continuing trend of male dominance in politics. This is a pointer to the fact that a lot still has to be done to address the political problems confronting women in a rapidly changin $\mathrm{g}$ developing society. The increasing awareness by the society at large warrants that women should get more inv olved making conscious efforts to sensitize fellow women on the need for them to organize and coordinate their activities towards improving their positions in the society. 


\section{References}

[1]. [1] Adeyemi, G. \&Adeyemi, T. (2003): "Gender Issues in Nigerian Politics" in Kwanashie, M. (ed), Politics andPolitical Power Relations in Nigeria.Oshodi, Dat\& Partners Logistics Ltd.

[2]. Afisunlu, Feyi (2013): "Professor Adelabu sworn in as Ekiti State Deputy Governor". @dailypost.com.ng accessed on 10th Nov., 2013.

[3]. Almond, G. A. \&Verba, S. (1963): The Civil Culture- Political Attitudes and Democracy in Five Nations. Boston, Little Brown \& Co.

[4]. Anifowose, R (2003): “Theoretical Perspectives on Elections” in Anifowose, R. \&Babawale, T. (eds), 2003 General Elections and Democratic Consolidation in Nigeria. Lagos, Friedrich Ebert Stiftung (FES).

[5]. Charles I.E \&Ikenna M.A (2007): "Electoral Process and Gender Discrimination in Nigeria" A Case Study of 2003 and 2007 General Elections. (http://www.jsd-africa.com/Jsda/V10N4-Spring2009/PDF/ElectoralProcessGender.pdf

[6]. Epelle, A.Oriakhi F.O.U (2003): "Active Participation of Women in Nigerian Politics: Lingering Obstacles, New Hopes".International Journals of Governance and Development Vol1,No2. Institute for Governance and Development, Ekpoma.

[7]. FasuanOladeji (2002): Creation of Ekiti State. The Epic Struggle of aPeople.Ado-Ekiti. Industrial \& Merchandise Nig. Ltd.

[8]. Igwe, Obasi (2002): Politics and Globe Dictionary. Enugu, Jamoe Enterprises Nigeria

[9]. Milbrath, L. (1965): Political Participation- How and Why do People Get Involved in Politics? Chicago, Rend McnallyCompany.

[10]. Nda L. Hamalai (2003): "Women in the Power Equation of Nigerian Politics" in Mike Kwanashie (ed),Politics and Political Power Relations in Nigeria. Lagos,Dat\& Partners Logistics Ltd.

[11]. Oke L. (2004):"Women and the State of Development in Nigeria". inAgagu A.A. \& Ola R.F. (eds), Development Agenda of the Nigerian State. Ibadan, FIAG (Nig) Publishers.

[12]. Olaoye, e. o. (2007): "Vote-Buying and Election Rigging in Nigeria Politics" in Femi Omotoso (ed), Readings in PoliticalBehaviour.Ado-Ekiti, University of Ado-Ekiti Press.

[13]. Oluwatusin, A. O. (2007): "Godfatherism, Violence and Electoral Politics in Nigeria" in Femi Omotoso (ed) Readings I Political Behaviour. Ado- Ekiti. University of Ado-Ekiti Press.

[14]. Omotoso F. (2002): "Electoral Politics under the Abacha Regime" in Kolawole D and Mimiko N.O. (eds), Political Democratization and Economic Deregulationin Nigeria under the Abacha Administration 1993 - 1998.Ado-Ekiti,Department of Political Science.

[15]. Quadri, L. (1965): "Urbanisation, Women and Political Participation in Nigeria" in Adejugbe, M.O.A. (ed) Industrialisation,Urbanisation and Development in Nigeria 1950-1999. Lagos, Concept Publications Ltd.

[16]. Soetan, F. (1995): "Democratisation and the Empowerment of Women: The Traditional and Modern Women'sAssociation in Nigeria" in Dele Olowu, Soremekun, K. \& Adebayo Williams (eds), Governance and Democratisation. Ibadan, Spectrum Books Ltd. 